\title{
Virtual communication in middle school students' and teachers' inquiry
}

\author{
Lakkala, Minna
}

Lawrence Erlbaum Associates (LEA)

2002

Lakkala , M , Ilomäki , L , Lallimo , J \& Hakkarainen , K 2002 , Virtual communication in middle school students' and teachers' inquiry . in G Stahl (ed.), Proceedings of Computer Supported Collaborative Learning 2002 Conference : Proceedings of CSCL 2002 . Lawrence Erlbaum Associates (LEA), Hillsdale, NY , pp. 443-452, CSCL 2002 Conference, Boulder, Colorado, United States, 07/01/2002.

http://hdl.handle.net/10138/154430

acceptedVersion

Downloaded from Helda, University of Helsinki institutional repository.

This is an electronic reprint of the original article.

This reprint may differ from the original in pagination and typographic detail.

Please cite the original version. 
Lakkala, M., Ilomäki, L., Lallimo, J., \& Hakkarainen, K. (2002). Virtual communication in middle school students' and teachers' inquiry. In G. Stahl (Ed.), Computer Support for Collaborative Learning: Foundations for a CSCL community. Proceedings of the Computer-supported Collaborative Learning 2002 Conference (pp. 443-

452). Hillsdale, NJ: Erlbaum.

\title{
Virtual communication in middle school students' and teachers' inquiry
}

\author{
Minna Lakkala, Liisa Ilomäki, Jiri Lallimo and Kai Hakkarainen \\ Department of Psychology, University of Helsinki \\ Minna.Lakkala@helsinki.fi \\ http://www.helsinki.fi/science/networkedlearning
}

\begin{abstract}
The aim of the study was to evaluate an innovative learning project in which middle school students and teachers completed chosen, group inquiries through virtual collaboration in a web-based learning environment. The students' task was to accomplish a cross disciplinary inquiry into cultural phenomena. Students worked mainly at home during the project and took much responsibility for their own work and course achievements. The investigators analyzed the content of the students' and teachers' communication in the web-based environment. The findings suggest that the virtual environment was used as a communication tool for organizing the collaborative work more than as a genuine knowledge-building tool. Also, the tension between the conventional school culture and the novel working practices apparently affected students' participation and patterns of activity in the course.
\end{abstract}

\section{Keywords}

Collaborative knowledge building, virtual learning, progressive inquiry, middle school

\section{INTRODUCTION}

This study concentrates on analyzing a virtual inquiry based learning project in middle school which differed from conventional school projects in many ways. Middle school students worked mainly off the school premises and communicated with each other and with teachers from home through a web-based learning environment. The project was organized under a very wide inter-disciplinary concept of culture, and it integrated students' work in several subject domains and school courses. The project was also untypical in that several teachers from different subject-domains took part in each group inquiry, jointly carrying out the pedagogical planning, and students' guidance and evaluation.

The teachers had an ambitious goal to introduce students to practices of collaborative knowledge building. Scardamalia and Bereiter $(1994 ; 1999)$ have proposed that schools should be restructured towards knowledgebuilding organizations, in which students and teachers participate in the construction of collective knowledge as in professional research groups where the object of activity is solving knowledge-problems. The participating teachers were introduced by the researchers to the model of progressive inquiry, which has been developed by Hakkarainen and his colleagues (Hakkarainen \& Sintonen, in press; Muukkonen, Hakkarainen \& Lakkala, 1999) as a pedagogical model for promoting knowledge-building practices in schools with the support of collaborative technology. In progressive inquiry, students are guided to engage in a research-like process by defining problems and proposing working theories, using information sources and collaboratively formulating new higher-level problems and explanations. The methods were also new to the teachers, so they were genuinely in a novice's role themselves.

Another background goal for the evaluated project was to advance virtual learning practices on all levels in Finnish schools (Ministry of Education, 1999). There is a need to develop models for practical applications of technology-supported virtual learning in real school contexts. Most research and development that has been done on CSCL in lower school levels has been in face-to-face classroom situations (e.g., Salovaara \& Järvelä, 2001). There are fewer studies of the challenges of collaborative knowledge building in distance learning situations. In 
this school project, one aim was to give the students an experience of technology-supported virtual working. The participating students did not belong to a traditional classroom community, but were gathered together especially for this course. Therefore, the challenges for organizing the learning community in the project can be compared to the challenges for building virtual communities in general. Elements that characterize successful virtual communities are e.g., shared goals and resources, active participation and reciprocal interaction, sense of belonging, trust in others, and shared context of social conventions (Schuler, 1996; Preece, 2000). According to Schuler (1996), development of a networked community requires organizing the mechanisms that "describe the general decision-making, responsibility allocating, and communication methods that will guide the group" (p. 338). In a study of university students' virtual learning process, Muukkonen et al. (1999) mentioned the issue of community building as one of the major challenges in using CSCL in education. They argued that to intensively participate in virtual learning environments, the students need strong community support to help induce them to participate.

The features of the virtual tool used for collaboration are of course important factors in facilitating the process. In this project the students and teachers used a web-based learning environment, in which the main collaborative tool was a quite typical threaded discussion forum. The same kinds of forums are widely employed as easy-to-use tools in learning situations. Guzdial and Turns (2000) have evaluated the effectiveness of the communication in selected virtual discussion forums for learning. They defined three necessary conditions for demonstrating whether the activity in the networked discussion supports learning: The discussion should be sustained (which they evaluated from the length of discussion threads), it should have broad participation and it should focus on class topics.

A third important dimension in studying innovations in schools is the effect of the whole conventional school culture on the new, collaborative process. As Engeström, Engeström and Suntio (in preparation) presented in their study of school change in the framework of cultural-historical activity theory, there are deep structural constraints in developing the school: Socio-spatial structure of the school work (separate classrooms, teachers working alone, isolation of the school from the environment), temporal structure (discrete and short lessons, test and grading phases etc.) and motivational and ethical structure (grading as a main motivational method). Bielaczyc (2001) has stated that the central challenge in implementing CSCL in schools lies in creating the appropriate social infrastructure for collaborative activity. She defines social infrastructure as having three levels: 1) A cultural level includes classroom culture and philosophy and norms established; 2) an activity level comprises the classroom practices and online activities in the process; 3) a tool level defines, how the participants structure the technological environment and use the possibilities of the CSCL tool. In the evaluated project the teachers' intention was deliberately to surpass the limits of the classroom and restrictions of separate subject domains, but they still acted in a conventional school context with no extra resources or changes in the official curriculum.

In summary, the framework for analyzing the challenges of the virtual school project was found in the interaction and contradictions of three elements, as Figure 1 describes.

\section{Progressive inquiry goals}
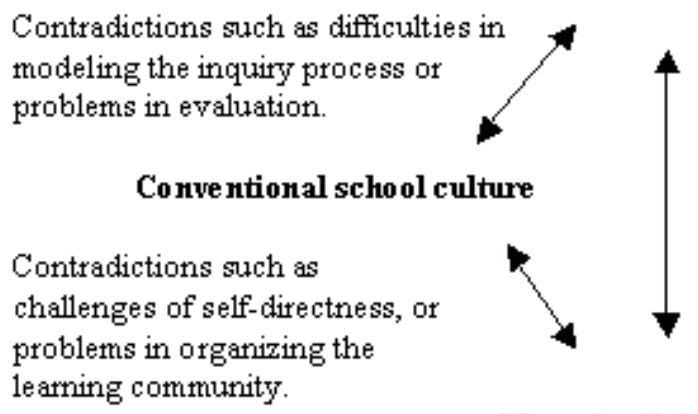

Contradictions such as problems in understanding the meaning of sharing knowledge, or concentration on practical process organization is sues instead of epistemic inquiry.

\section{Virtual collaboration}

Figure 1. Dimensions for examining the virtual school project.

Research questions that are based upon the framework were as follows: 1) How was the socially shared character of inquiry realized in the participants' technology-supported communication? 2) What additional elements did the 
virtuality and distance work bring into the inquiry process? 3) How did the virtual inquiry practices fit with the demands of the conventional school culture?

\section{METHODS}

\section{Setting and participants}

The evaluated 'Culture course' was organized in Alppila School, which is a middle school in the city of Helsinki. The school is quite advanced and active in developing learning and teaching methods: The emphasis in all teaching is on cultural aspects of the phenomena under study; the studying is organized through courses that meet periodically, not fixed classes; the school has participated in various research and development projects for several years.

The investigated project had, at the end, 14 student participants (age 15-16) and 7 teachers (computer science, biology and geography, religion, history and philosophy, arts, music, Finnish language). The students volunteered to participate in the course. They were all quite high achieving and were meant to complete several regular school courses by participating in the Culture course. It was the students' last spring in the obligatory lower secondary school. The teachers did not participate full-time in the course, but were at the same time responsible for other school courses as usual. The computer teacher was a coordinator of the whole project; other teachers participated as experts and tutors of their own subject domain.

The goal of the Culture course was to deepen students' (and teachers') conception of culture, to give students an opportunity to get experience of distance learning and to introduce students to the progressive inquiry approach. Students were encouraged to produce an innovative cultural product as a final work of the course, not just a traditional project report. The students decided among themselves the actual topic of their inquiry. They worked mainly off the school premises during the course. There were seven common meetings at school, otherwise the students communicated through the web-based learning environment from home, or arranged face-to-face meetings with their small group members and the guiding teachers. The actual distance-working period lasted seven weeks from February to April, but the whole project started two months beforehand with some preliminary meetings.

The technology used in the course was a web-based collaborative software called Virtual Web School (VWS; http://mauri.edu.hel.fi) designed by the Media Center of the Helsinki City Department of Education. A typical threaded discussion forum was the main tool for organizing the discourse. In addition, the learning environment included a chat tool and a text-based portfolio for students' private products, but they were not in active use in this course. It was not possible, for instance, to share documents through the VWS.

\section{Data collection}

The data that have been analyzed in this study included the database notes posted to the VWS environment during the course. Five (out of seven) joint meetings in school were observed and videotaped by the researchers. One researcher participated to two teacher meetings, where teachers planned the organization of the course. In addition we obtained various materials about course accomplishments, final works and written course evaluations.

\section{Data analysis}

Several quantitative measures of the features of the virtual discourse - such as number of the postings, distribution of postings in time, and length of the discussion threads - were counted from the discussion threads in the VWS.

The postings to the VWS database were also analyzed qualitatively using the methods of qualitative content analysis (see Chi, 1997) to evaluate the patterns of collaboration in the virtual learning community. The unit of analysis was one message or posting. Messages were categorized according to the main content of the message text: what appeared to be the main purpose or object of the posting in the discourse. The categories were derived from the several preliminary analyses of the data. The following five were used in the final classification:

1) Content of the inquiry: These messages represented students' problems, thoughts and explanations of the inquiry topics and subject domain concepts, descriptions of the content of their inquiry, and teachers' contentspecific guidance.

2) Community building: Messages in this category represented general discussion relating to the common purpose of the learning community (progressive inquiry, collaborative work, accomplishing inquiry about culture), communication about the ways of using the virtual tools (organizing the forums, using sensible titles), and social aspects of the community (arranging a common meeting room, invitations to participate actively to virtual work). 
3) Process organization: Messages in this category included communication that was needed for organizing the inquiry work of separate small groups (arranging meetings, asking help or comments, telling about information sources, making agreements of task completion).

4) Course evaluation: Messages in this category included questions, agreements and arguments about the rules for completing the project work, criteria for course grading and general timetables or deadlines.

5) Other issues: Messages put into this category included conversation about other topics or school activity unrelated to the project tasks, and nonsense test messages written by students in the practicing phase.

Each message was classified in only one of the content categories, according to its main content. Content analysis was performed using ATLAS/ti-program. To analyze the reliability of classification, an independent coder classified approximately $17 \%$ of all messages (randomly selected message threads from a general forum and all the messages from one group forum); the coefficient for rater agreement (Cohen's Kappa) was .85, which was considered satisfactory.

Other material and observational data from the course meetings and teacher meetings were used as complementary information to get an overview of the process, and to interpret the communication in the virtual environment in a larger context.

\section{RESULTS}

\section{Structure and organization of the course}

Below is a description of the structure and phases of the course.

\section{Preliminary phase}

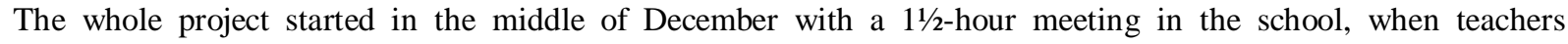
introduced the course and its objectives to students. Students seemed to be insecure about the requirements and goals of the project. At least four high-achieving girl students who had originally reported to the project withdrew from it in the first meeting. They stated that it is 'safer' to work in traditional courses because they wanted to get the highest degrees to their final middle school report. In the middle of January, the computer teacher gave the participants a training session on the VWS-environment. Also the reasons for using the collaborative tool were discussed, and the general forum entitled 'Small talk' was founded for practicing. The teacher gave students a task to write their individual inquiry plans to the VWS forum entitled 'Working plans and starting theories' before the next meeting. In the beginning of February, the philosophy teacher arranged a brainstorming session in the school, meeting hall. Students planned the content of their inquiry work in the framework of various cultural dimensions (past-present-future, fact-fiction, etc.). Also discussed were decisions about the small groups, tutoring teachers and school courses that the students would complete. After the meeting the students continued the planning virtually in the VWS.

\section{1st week}

The fourth school period started in the middle of February when the students started their actual distance work. In the first week, the computer teacher gave a lecture about progressive inquiry at school; students formed small groups and decided the topics of their group's inquiry. The students formed 7 groups and formulated the following research topics: Biological effects of music ( 2 boys), Life in the Middle Ages ( 2 boys), Effects of genes and environment on a Finnish-Australian girls' life ( 2 girls), Japanese culture (1 girl alone), American Indian culture ( 2 boys), Comparison of Finnish and Canadian cultures ( 2 girls) and Aspects of religion and society (3 boys). Each group had a main, tutoring teacher, but all the teachers were meant to guide all students and give support especially to those students who were completing courses in their teaching subject. The students had chosen 2-6 school courses that they would complete by participating in the Culture course. At the end of the first week the students had another working session in the computer lab. Their task was to write to the VWS their group's research questions and starting theories, and comment on other groups' plans.

\section{From $2^{\text {nd }}$ to $6^{\text {th }}$ week}

During the next five weeks (from the end of February to the beginning of April) students did independent work and organized their group processes using the VWS. In the second week separate, specific discussion forums were founded for every group (everybody was allowed to participate freely in the group forums and the common forums). Students were guided to start the investigation of their research questions. During these weeks, students processed 
their work in their respective group forums but also discussed issues in joint forums. In addition they had face-toface meetings with their own group and the tutoring teachers.

\section{$7^{\text {th }}$ and $8^{\text {th }}$ week}

In the seventh week (in the beginning of April) there was a common face-to-face meeting, in which the groups commented on the state of each other's work. The teachers guided the students to think about high points and new interesting aspects in each group's inquiry work. After that day the small groups continued their process, mostly finishing their final work and making plans about how to present it in the closing event. In the last week (in the middle of April) there was a 4-hour closing event at the meeting hall. Each group presented its final work in a different way. The Middle Ages group had made a radio play; the Canada group had written an imaginary diary of a school girl who was visiting Canada as an exchange student. At the end of the week the students were called to school once more to write their evaluation of the course for the researchers. In the Culture course the students received credit for 61 courses in all, according to the agreements; 4.4 courses per student on average.

\section{Amount of activity and threading of the virtual discourse}

The participants posted 534 messages to the VWS database during the project (minimum was 3 messages of a boy student; maximum, 81 messages of a male teacher). Students $(\mathrm{N}=14)$ posted 308 messages $(\mathrm{Mean}=22.0, \mathrm{SD}=$ 29.9) and teachers $(\mathrm{N}=7$ ) posted 226 messages (Mean $=32.3, \mathrm{SD}=26.0)$. Some of the messages were written by two or three students together. In the joint forum entitled 'Small talk' were 168 messages; in the 'Plans and theories' forum, 113 messages; and in seven, group forums there were 253 messages in all. In Figure 2 one can see how the volume of messaging varied in discussion forums during the course.

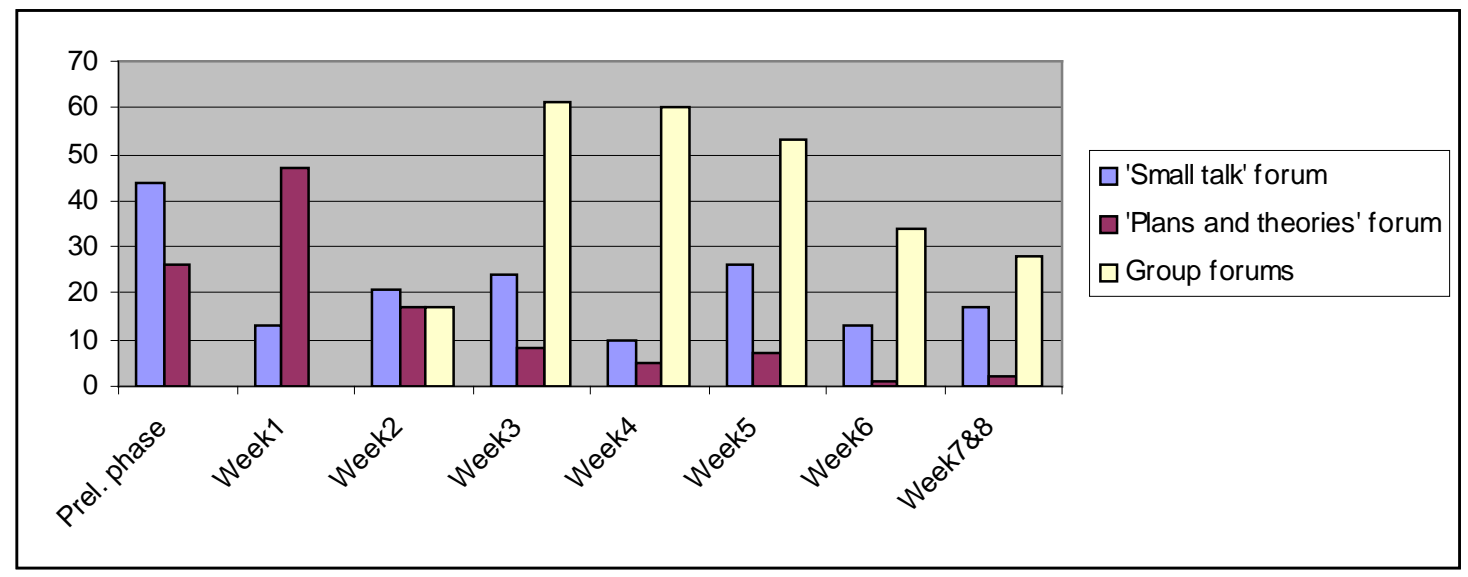

Figure 2. The number of messages in the discussion forums in course weeks.

In the beginning of the project, only the two general forums were in use. As Figure 2 shows, in the first, course week, the work was concentrated on the 'Plans and theories' forum according to the teachers' instructions. After the second week, the communication was transferred mainly to the group forums, and it was most active in the middle of the course.

In all the virtual forums together, there were 218 top-level messages (41\% of all messages), which were considered as new initiations in the discourse. Of those messages, 97 (44\%) were isolated messages that did not have any comments following, and 121 (56\%) were messages that had at least one comment; e.g., they had started a new discussion thread. Mean number of messages in discussion threads (in the threads that included at least two messages) was 3.63 ( $\mathrm{SD}=2.15)$. The longest thread included 14 messages, and only three threads had more than ten messages. Studies from the elementary level (Lipponen et al., 2001) and university level (Guzdial \& Turns, 2000) have given the same kind of results; that, in general, the discourse threads in virtual forums are quite short, which indicates that the inquiry, insofar as it is accurately reflected in the postings, is not very sustained or convergent.

There was a big difference in the use of each group's forum. Minimum number of postings in one forum was 13; maximum was 56. Mean number of postings in all group forums was 38.2 (SD = 14.9). We also counted the number of postings that the students sent to the forums of other groups. Only 8 (out of 253) messages in the group forums were written by students from the other groups; all other messages were written by the students of that 
group or by the teachers. After forming the small groups, the students obviously concentrated on their own work and did not contribute to other groups' work, although they where encouraged to do so.

\section{Content of the virtual communication}

Each posting to the VWS discussion forums was assigned to one of the content categories described earlier. The original goal of the project was to use the technology to support sharing and building of knowledge, which means sharing theories and explanations of cultural aspects in the students' inquiry. According to the content analysis, only $180(34 \%)$ of the postings were about the Content of inquiry. The frequencies of other content categories were as follows: Process organization messages 129 (24\%), Community building messages 105 (20\%), messages about Course evaluation 67 (12\%), and messages about Other issues 67 (10\%).

The discussion forums obviously had different roles in the communication of the learning community. In the 'Small talk' forum half (50\%) of the postings were community building messages, and about $25 \%$ were messages about issues unrelated to the common course goals. In the other joint discussion forum, the 'Plans and theories' forum, $64 \%$ of the postings were about the content of inquiry. In the seven group forums most of the communication was about the content of inquiry (42\%) or process organization $(42 \%)$.

The content of communication varied remarkably during the successive weeks of the course (Figure 3).

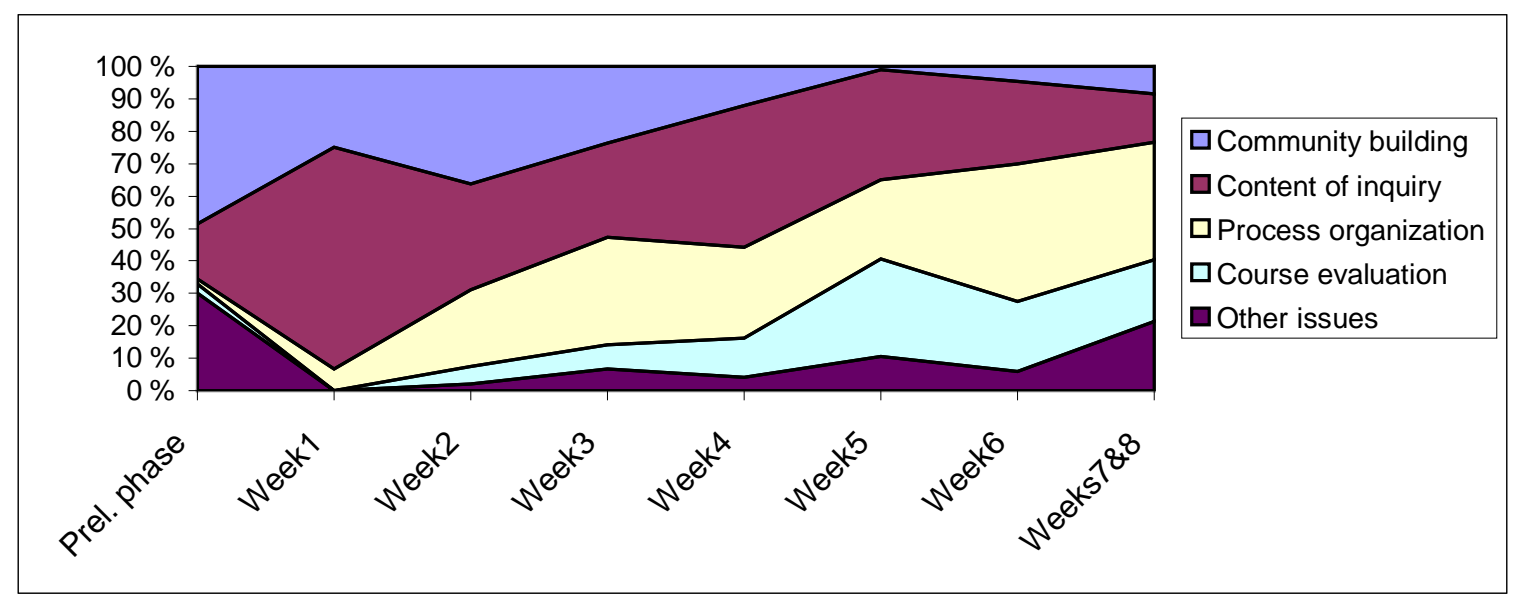

Figure 3. Change in the content of postings to the VWS discussion forums during the project.

As can be seen from Figure 3, in the beginning of the project, issues that were important for building up the learning community (common objectives and working methods) were dominant in the virtual communication. There were discussions about how to use the virtual tools, the importance of collaboration, and also plans to organize a joint working room for the course members in the school. Here is an example of messages assigned to the category of community building:

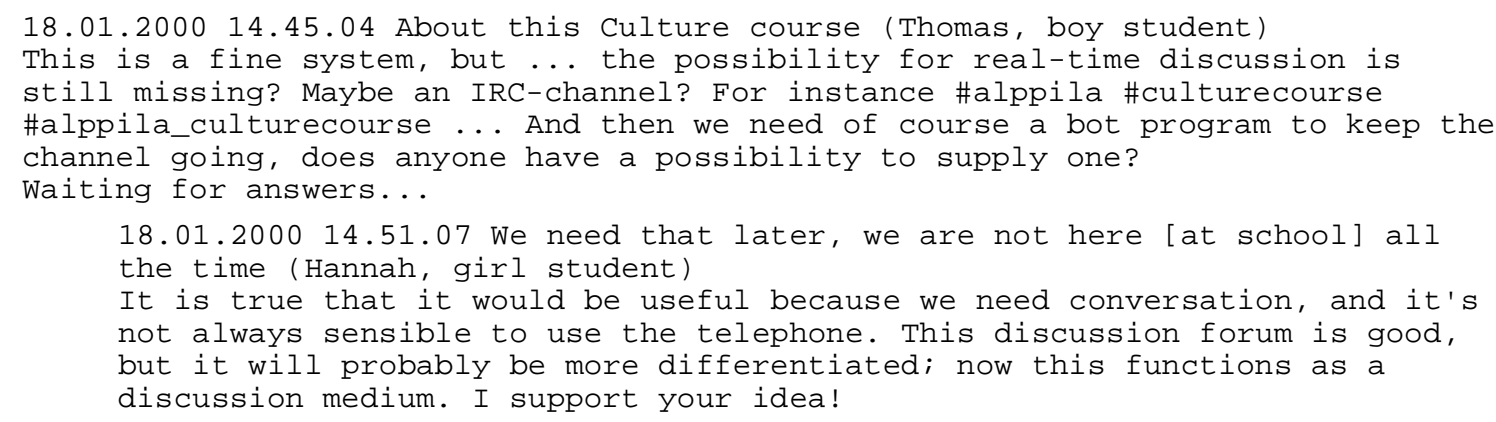

The number of messages about other issues unrelated to the Culture course was large in the preliminary phase, probably because then the students and the teachers were practicing their use of the virtual environment. In the session in which the participants were trained to use the VWS environment, $42 \%$ (27) of the posted messages were classified as community building messages, and 32\% (21) as messages about other issues. Teachers did not direct the first practices with the VWS to content-related inquiry work (a notice from a videotaped training session). 
The number of messages in the content of inquiry category was largest in the first week of the course period, when there was also another hands-on session in the school. In that period students were guided explicitly to define their plans, questions and starting theories of their inquiry to the virtual forums. The following is an example of contentrelated discourse:

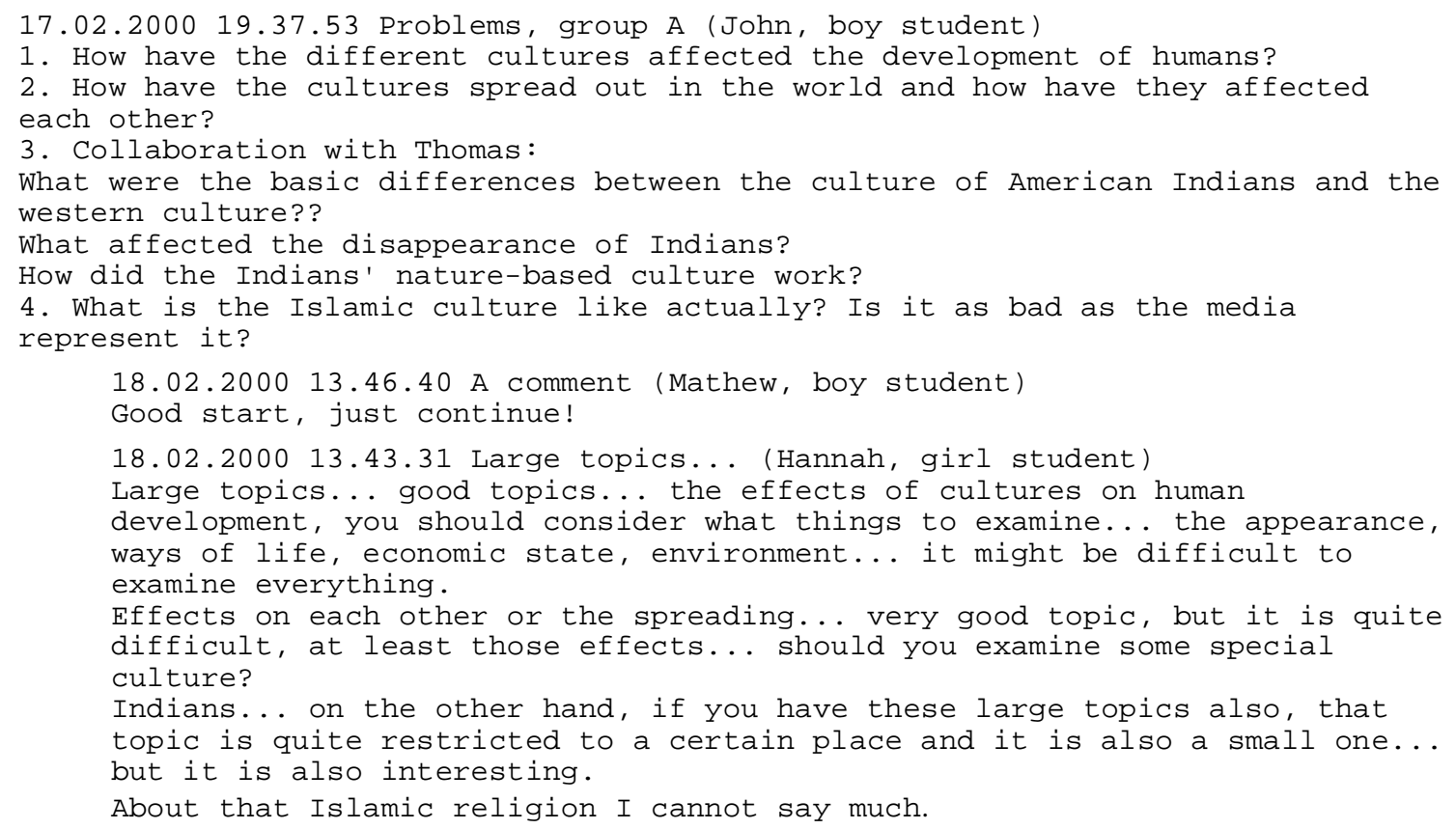

Especially later in the course most of the content messages were about designing the content of the final work. Here is an example of the message from the Australian group:

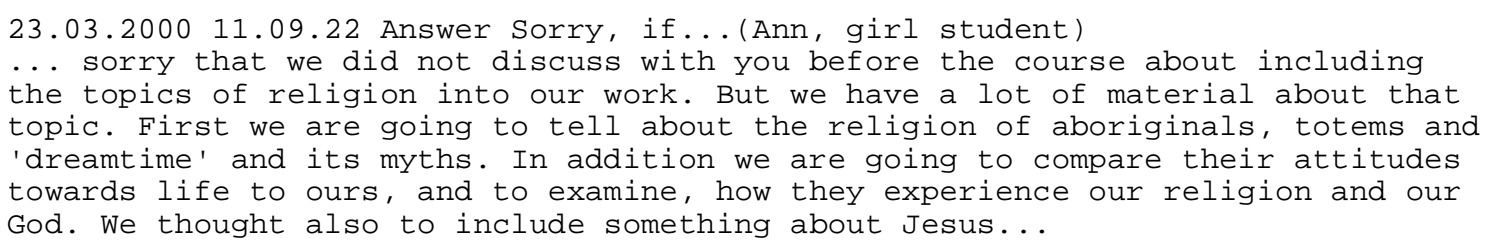

Teachers' content-related postings were mostly guidance for the inquiry process. For example:

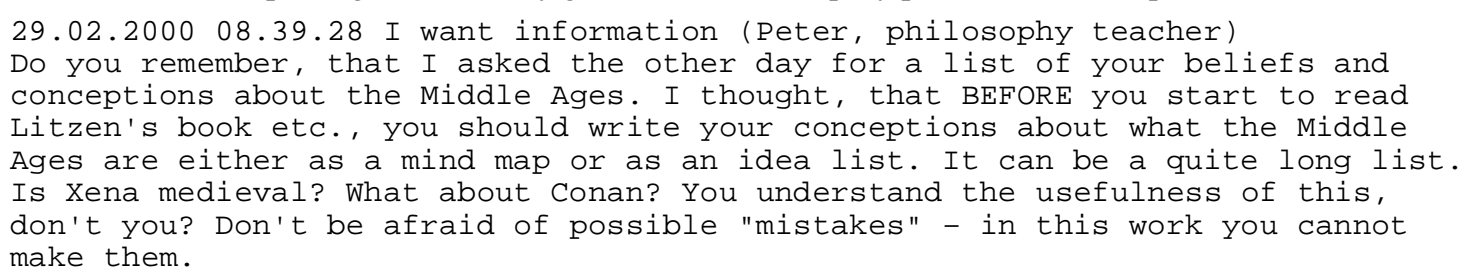

According to the analysis, very little of the content-specific discussion was actual conceptual discourse or formulation of research questions and explanations. The students and the teachers did not actually use the virtual environment very much as a forum for collaborative knowledge building, or for sharing of knowledge productions. Most of the content-related knowledge construction probably happened in face-to-face meetings with the group members and the tutoring teachers, not through the VWS.

In the VWS the amount of process organization messages increased after the small groups were formed, and it continued to increase towards the end of the course. Many of the process organization messages handled daily, practical things such as arranging meetings or explaining activities to be done. The following is an example of process organization discourse in the Music group:

09.03.2000 17.09.11 How are you (Susan, music teacher)

What is the situation in the research about the biological effects of music, or are you still planning it. Regards, Susan

09.03.2000 22.48.04 Thanks, very well... (Jerry, boy student) 


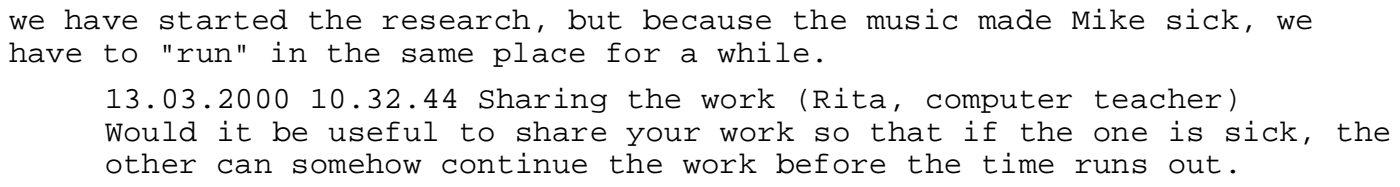

During the course the students prepared a presentation of their course work and presented it in the closing event. Planning of the concrete presentation was also one dominant theme in the process organization messages. The discussions were more like those in traditional school projects where the form of the end product starts to dominate as the object of the work.

Toward the end of the course, questions about course evaluation, rules and study criteria started to interest the students more, and it seemed to have been a problem that the criteria were not clearly specified in the beginning. The original goals of the course had been quite advanced ideas about knowledge building and progressive inquiry, but towards the end the teachers and the students had to enter into agreement about course completion according to the curriculum. One of the longest and 'hottest' discussion threads (12 messages) in the virtual environment was about course evaluation and deadlines for the work. For example, one girl student had problems with understanding the idea of getting comments and revising the work:

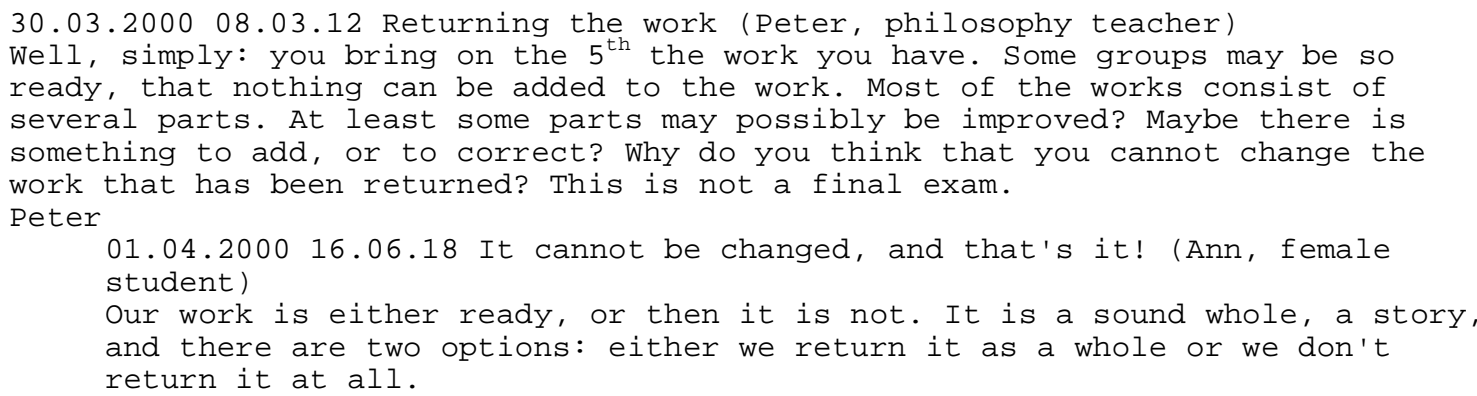

Two female students even refused to come to the evaluation meeting after the course had ended because they had not yet come to an agreement with the teachers about their course grades. There was an obvious contradiction between the traditions and demands of the conventional school culture and the new goals of virtual, collaborative inquiry work.

\section{Differences in the students' and the teachers' contribution to virtual communication}

We wanted to examine whether there were differences in the students' and the teachers' activity in the virtual collaboration. The evaluated project was suitable for comparing students and teachers because there were so many teachers involved compared to the number of students, although most teachers' contribution to the project was rather small.

In Table 1 are presented the general frequencies and proportions of each message content category in the students' and the teachers' messages. The general content profiles did not differ much (correlation of the distribution was 0.71). According to $\chi 2$-test there was a significant difference between the groups $(\chi 2=26.8$, $\mathrm{df}=4, \mathrm{p}<.001)$. Cellspecific exact tests (Bergman \& El-Khouri, 1987) were carried out in order to examine whether the observed frequencies in each cell deviated from what could be expected by chance alone.

Table 1. Contents of the students' and the teachers' messages in the VWS discourse forums.

\begin{tabular}{lrrrr} 
& Students $(\mathbf{N}=\mathbf{1 4})$ & \multicolumn{2}{c}{ Teachers $(\mathbf{N}=7)$} \\
Content category & $\mathrm{f}$ & $\%$ & $\mathrm{f}$ & $\%$ \\
\hline Content of inquiry & 104 & 34 & 76 & 34 \\
Community building & 65 & 21 & 40 & 18 \\
Process organization & $55^{*}$ & 18 & $74^{\dagger}$ & 33 \\
Course evaluation & 40 & 13 & 27 & 12 \\
Other issues & 44 & 14 & $9^{*}$ & 4 \\
\hline Total & 308 & 100 & 226 & 100 \\
Note. Significance tests are based on binomial probability estimations (Bergman \& El-Khouri, 1987); \\
$*=$ Observed frequency smaller than expected by chance alone (p < .01); \\
$\dagger=$ Observed frequency larger than expected by chance alone (p < .01).
\end{tabular}


The results indicated that in the virtual communication, the teachers concentrated more than the students on organizing the group processes, although we expected that the teachers would take more responsibility for the advancement of epistemic and content-specific inquiry. Also intriguing is that both the teachers and the students took responsibility for organizing the work of the whole virtual community and keeping the virtual work active. A quite expected result is that the students had more postings than teachers, of other than project-related issues.

Another indication of the teachers' strong efforts to organize the group work through the virtual environment was the high proportion of the teachers' postings to the small groups' discussion forums. Teachers had written $57 \%$ (145) of the 253 messages in the group forums. Obviously, the students themselves did not use the virtual tool for their own collaboration, but did the actual work in face-to-face meetings. The virtual tool was used more as a communication channel between the students and the teachers.

\section{DISCUSSION AND CONCLUSIONS}

In this investigation we analyzed how middle school students and teachers succeeded in practicing virtual collaborative inquiry. We wanted to document the challenges encountered in applying new ways of working and to find indications of emerging innovative pedagogical practices. As Windschitl (1998) pointed out, qualitative research approaches are valuable in investigating phenomena in novel fields, such as technology-supported virtual learning applied in schools. The evaluated school project succeeded in surpassing many structural constraints in the school. Both the students and the teachers participated very enthusiastically and were motivated to experiment with progressive inquiry and virtual collaboration. The students took much responsibility for their distant work and completed many middle school courses from subject domains during the project. The final products of the small groups were large, multidisciplinary and unique cultural products.

First, we were interested in the realization of collaborative inquiry in the technology-supported communication. The features of progressive inquiry and joint knowledge construction were more obvious in the beginning of the course, when the teachers explicitly directed the virtual process towards formulation of research questions and theories about the cultural phenomena. Later in the course the web-based learning environment was not used for actual building of knowledge objects or for sharing expertise; the virtual communication (of both the students and the teachers) changed towards the organization of practical task-accomplishment issues. There are probably several reasons for this change. The organization of the course in sub-groups that had very divergent topics reduced the necessity for joint, knowledge sharing in the whole learning community. The web-based learning environment used did not have very sophisticated tools for higher-level knowledge building: the main collaborative tool was a threaded discussion forum, which did not allow sharing and modifying of joint digital artifacts, or did not include advanced built-in scaffolds for inquiry as CSILE (Scardamalia \& Bereiter, 1994; http://csile.oise.utoronto.ca) or Future Learning Environment (Muukkonen et al., 1999; http://fle2.uiah.fi). In addition, the students would obviously have needed more scaffolding in progressive inquiry, and more attention should have been given to the conceptual and theoretical goals of the course.

Second, we wanted to evaluate how the virtuality affected the inquiry process. Virtual work evidently needs a different kind of organization than CSCL practiced in face-to-face classroom situations. The great amount of communication concerning community-building issues in the beginning of the project indicates the necessity, mentioned by Schuler (1996), to make agreements of the collective work habits. Actually, in the virtual interaction, the students themselves quite skillfully took responsibility for issues of shared goals and social conventions. All the participants contributed to the virtual discourse, but the participation was quite unevenly distributed. The discourse was either not very sustained or not very topic-centered. The great number of process organization messages, especially in the small groups' forums showed that virtual collaborative inquiry needs a communication channel also for practical coordination of the work. More like epistemic inquiry, the communication resembled patterns of design process, as in a virtual project of textile students studied by Lahti, Seitamaa-Hakkarainen and Hakkarainen (2001), where over $20 \%$ of students' postings to a virtual learning environment were about process organization.

Third, we were interested in seeing how the virtual inquiry practices fit in the demands of the conventional school culture. The incompatibility of the new working methods and the school culture emerged as an important issue in the course. To begin with, some students withdrew from the whole course because they felt uncertain about getting the highest degrees in that way. Also, in spite of the high-level goals of the course for accomplishing collaborative multi-disciplinary inquiry, the teachers still had to grade students' work according to courses in the official curriculum. Based on the content analysis of the virtual discussions, we concluded that the lack of explicitly 
defined criteria in the beginning of the course caused problems to students both in planning the content of inquiry and in the timing of the work. In addition, the time of the course was not ideal for radical experimentation because the students were worried about their grades in the final, middle school report.

The participants had two demanding new challenges in the project at the same time: progressive inquiry and virtual work. A better structured process with commonly known and accepted goals, rules, and evaluation principles may have helped students to carry out a more profound inquiry process. If the participants had been more low-achieving students, they would have needed even more support and guidance. In general, children should have a possibility of practicing new working methods safely at school without the demands of grading; and growing up to a modern, knowledge building culture has to happen gradually throughout the whole school life.

\section{ACKNOWLEDGMENTS}

The first author was supported by grant from the Finnish Cultural Foundation. 


\section{REFERENCES}

Bergman, L. \& El-Khouri, B. (1987). Exacon: A Fortran 77 program for the exact analysis of single case cells in a contingency table. Educational and Psychological measurement, 47, 155-161.

Bielaczyc, K. (2001) Designing Social Infrastructure: The Challenge of Building Computer-Supported Learning Communities. In Dillenbourg, P., Eurelings, A. \& Hakkarainen, K. (Eds.) European Perspectives on Computer-Supported Collaborative Learning. Proceedings of the First European Conference on CSCL, March 22-24, 2001, University of Maastricht, the Netherlands. http://www.mmi.unimaas.nl/eurocscl/Papers/15.doc

Chi, M.T.H. (1997). Quantifying qualitative analyses of verbal data: A practical guide. The Journal of the Learning Sciences, 6, 271-315.

Guzdial, M. \& Turns, J. (2000). Effective Discussion Through a Computer-Mediated Anchored Forum. The Journal of the Learning Sciences, 9(4), 437-469.

Engeström, Y., Engeström, R. \& Suntio, A. (in preparation). Can a school community learn to master its own future? An activity-theoretical study for expansive learning among middle school teachers. Available: http://people.ucsc.edu/ gwells/CHATbook/Ch16.Engestrometal.html

Hakkarainen, K. \& Sintonen, M. (in press) Interrogative approach on inquiry and computer-supported collaborative learning. Science \& Education.

Lahti, H., Seitamaa-Hakkarainen, P., \& Hakkarainen, K. (2001). The nature of collaboration in computersupported designing. In Dillenbourg, P., Eurelings, A. \& Hakkarainen, K. (Eds.) European Perspectives on Computer-Supported Collaborative Learning. Proceedings of the First European Conference on CSCL, March 22-24, 2001, University of Maastricht, the Netherlands. Available: http://www.mmi.unimaas.nl/euro-cscl/Papers/96.doc

Lipponen, L., Rahikainen, M., Lallimo, J., \& Hakkarainen, K. (2001). Analyzing patterns of participation and discourse in elementary students' online science discussion. In P. Dillenbourg, A. Eurelings, \& K. Hakkarainen (Eds.), European perspectives on computer-supported collaborative learning. The proceedings of the First European Conference on Computer-Supported Collaborative Learning (pp. 421428). University of Maastricht. Available: http://www.mmi.unimaas.nl/euro-cscl/Papers/102.doc

Ministry of Education (1999). Education, Training and Research in the Information Society. A National Strategy for 2000-2004. Available: http://www.minedu.fi/julkaisut/information/englishU/index.html

Muukkonen, H., Hakkarainen, K. \& Lakkala, M. (1999). Collaborative Technology for Facilitating Progressive Inquiry: Future Learning Environment Tools. In C. Hoadley \& J. Roschelle (Eds.) The proceedings of the CSCL '99 conference, December 12-15, 1999, Palo Alto (pp. 406-415). Mahwah, NJ: Lawrence Erlbaum and Associates. Available: http://kn.cilt.org/csc199/A51/A51.HTM

Preece, J. (2000) Online communities. Designing Usability, Supporting Sociability. John Wiley \& Sons, Ltd, West Sussex, England.

Salovaara, H. \& Järvelä, S. (2001) CSCL in secondary school literature class - focus on students' strategic actions. In P. Dillenbourg, A. Eurelings, \& K. Hakkarainen (Eds.), European perspectives on computer-supported collaborative learning. The proceedings of the First European Conference on Computer-Supported Collaborative Learning (pp. 537-544). University of Maastricht.. Available: http://www.mmi.unimaas.nl/euro-cscl/Papers/139.doc

Scardamalia M. \& Bereiter, C. (1994). Computer support for knowledge-building communities. The Journal of the Learning Sciences, 3(3), 265-283.

Scardamalia, M. \& Bereiter, C. (1999) Schools as knowledge-building organizations. In D. Keating \& C. Hertzman (Eds.), Today's children, tomorrow's society: The developmental health and wealth of nations (pp. 274-289). New York: Guilford. Available: http://csile.oise.utoronto.ca/abstracts/ciarunderstanding.html

Schuler, D. (1996). New Community Networks. Wired for Change. New York, NY: ACM Press \& Addison-Wesley Publishing Company.

Windschitl, M. (1998). The WWW and Classroom Research: What Path Should We Take? Educational Researcher, 27(1), 28-33. 